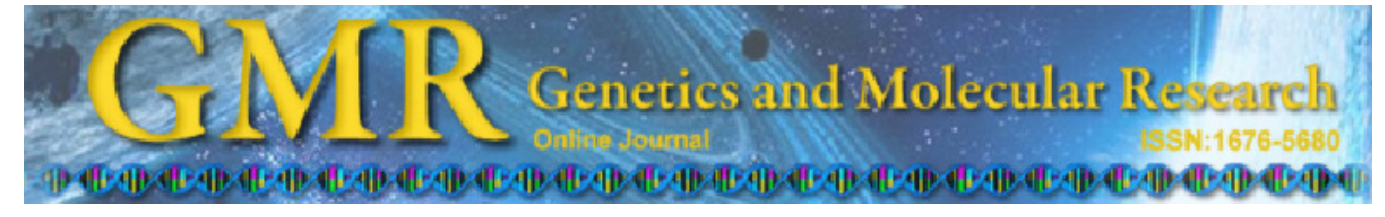

\title{
Marsdenia tenacissima extract sensitizes MG63 cells to doxorubicin-induced apoptosis
}

\author{
T. Huang ${ }^{1}$, W.H. Gong ${ }^{2}$, C.P. Zou ${ }^{1}$, X.C. Li ${ }^{1}$, G.J. Jiang ${ }^{2}$, X.H. Li ${ }^{2}$ and H. Qian ${ }^{1}$ \\ ${ }^{1}$ Department of Orthopedics, \\ The First Affiliated Hospital of China Medical University, Shenyang, \\ Liaoning, China \\ ${ }^{2}$ Beth Israel Deaconess Medical Center, Harvard Medical School, \\ Boston, MA, USA \\ Corresponding author: T. Huang \\ E-mail: huangtao@mail.cmu.edu.cn
}

Genet. Mol. Res. 13 (1): 354-362 (2014)

Received August 9, 2013

Accepted October 28, 2013

Published January 21, 2014

DOI http://dx.doi.org/10.4238/2014.January.21.3

\begin{abstract}
Marsdenia tenacissima extract (MTE) is a new platederived biotechnology product that is frequently used, but occasionally reported, in the field of chemotherapy. In this study, we assessed the antitumor activity and related mechanisms of MTE by various biotechnological methods. The survival rates of MG63 osteosarcoma cells treated with MTE and doxorubicin were measured, individually or jointly, and the changes in cellular shape, apoptotic rates, and Fas expression were observed. The results indicated that combination of MTE and doxorubicin up-regulated Fas expression and induced apoptosis. The survival rate of combined application of $50 \mathrm{mg} / \mathrm{mL}$ MTE and $1 \mu \mathrm{g} / \mathrm{mL}$ doxorubicin was significantly lower than that of the individual application $(\mathrm{P}<0.01)$. Other biotechnology methods also showed an apoptosis-inducing effect of combined application that was much stronger than individual application. All of these results suggested that MTE may promote the effects of doxorubicin chemotherapy, perhaps related to the up-regulation of Fas expression in tumor cells.
\end{abstract}

Key words: Marsdenia tenacissima extract; Doxorubicin; Apoptosis 


\section{INTRODUCTION}

Osteosarcoma is the most common primary tumor of bone, and early pulmonary metastasis is liable to occur with bad prognosis (Dotan et al., 2010; Broadhead et al., 2011). Although chemotherapeutic drugs such as doxorubicin has a killing effect on osteosarcoma cells, the resistance and toxic side effects after long-term application remain a main obstacle for clinicians (Zhang et al., 2011). Xiao-Ai-Ping injection, a product taken with biotechnology from the roots of Marsdenia tenacissima, is a well-known traditional Chinese medicine widely used in clinical cancer therapy for its lower side-effects in Asian countries (Lei et al., 2008; Zhang et al., 2010). M. tenacissima extract (MTE) has been proven clinically to enhance the antitumor effect and reduce the dosing of chemotherapeutic drugs. However, there have been a few reports on the application of MTE in osteosarcoma chemotherapy (Qian et al., 2009; Fang and Sun, 2011). We sought to conduct basic medical research with biotechnological methods to verify the potential effects of MTE on osteosarcoma cells before MTE chemotherapy is adopted by physicians in clinics. Therefore, we used MTE and doxorubicin, individually or jointly, on MG63 cells to explore whether MTE could induce apoptosis. We also examined whether the effect of MTE was related to up-regulation of the expression of Fas to analyze its antitumor mechanism and provide theoretical evidence for integrated antitumor treatment with biotechnology products and traditional chemotherapy drugs.

\section{MATERIAL AND METHODS}

The osteosarcoma MG63 cell line was donated from the School of Stomatology of the China Medical University. Dulbecco's modified Eagle's medium (DMEM) was purchased from Hyclone. Trypsin and MTT were from Huamei. MTE (Xiao Ai Ping injection) was provided by Sanhome Pharmaceutical Co., and doxorubicin was provided by Hisun Pharmaceutical Co. Polyclonal antibodies targeting Fas were purchased from Fuzhou Maixin.

\section{Cell culture and research methods}

The MG63 cell line was placed in DMEM with 10\% fetal bovine serum and cultured at $37^{\circ} \mathrm{C}$ in a humidified $5 \% \mathrm{CO}_{2}$ atmosphere. We selected $1,10,50$, and $250 \mathrm{mg} / \mathrm{mL}$ for the MTE individual group; $1,5,10$, and $100 \mu \mathrm{g} / \mathrm{mL}$ for the doxorubicin individual group; and 50 $\mathrm{mg} / \mathrm{mL}$ MTE with $1 \mu \mathrm{g} / \mathrm{mL}$ doxorubicin for the combined group. Phosphate-buffered saline was used as a vehicle for the control group. The experimental times were 24, 48, and $72 \mathrm{~h}$ after the treatment with different drugs and concentrations.

\section{Measurement of the survival rates of MG63 cells with MTT method}

Cells were seeded at a cell density of $5 \times 10^{5}$ cells $/ \mathrm{mL}$ on 96 -well plates, with $200 \mu \mathrm{L}$ in each well, and were added to the culture medium containing drugs of different concentrations. After culture for $24 \mathrm{~h}$ with 4 replicate wells, $20 \mu \mathrm{L}$ MTT was added at $37^{\circ} \mathrm{C}$ for $4 \mathrm{~h}$, and then the supernatant was discarded and dissolved in $150 \mu \mathrm{L}$ dimethylsulfoxide. The absorbance was measured at $540 \mathrm{~nm}$. The survival rate (\%) was calculated as follows: experimental group A value/control group A value x 100\%. 


\section{Observation of the morphology of apoptotic cells}

The morphology, number, and adherence of the tumor cells were directly observed with an inverted phase contrast microscope. A cover slide was placed on a 6-well plate, and after the apoptosis, the samples were fixed for $10 \mathrm{~min}$, stained with $0.5 \mathrm{~mL}$ Hoechst 33258 dye for $5 \mathrm{~min}$, and observed using fluorescence microscopy.

\section{Measurement of the proportion of apoptotic cells by flow cytometry (FCM)}

Cells were fixed with $70 \%$ cold ethanol for $48 \mathrm{~h}$. After centrifugation, the fixed cells were incubated with $200 \mu \mathrm{L} 10 \mathrm{~g} / \mathrm{L}$ RNase, washed to remove RNase, and then stained in darkness with $100 \mu \mathrm{L}$ propidium iodide at $4^{\circ} \mathrm{C}$ for $1 \mathrm{~h}$. The wavelength for FCM was $488 \mathrm{~nm}$, and the apoptotic rates were measured with the CellQuest analysis software.

\section{Immunocytochemistry to detect Fas expression in MG63 cells}

Digestive cells at a density of $2 \times 10^{5}$ cells $/ \mathrm{mL}$ were placed on a 6-well culture plate, with a pre-treated cover slide in each well, cultured for $24 \mathrm{~h}$, and then supplemented and incubated with drugs for $24 \mathrm{~h}$. Next, the cover slides were removed, fixed with acetone at $4^{\circ} \mathrm{C}$ for $10 \mathrm{~min}$, and stained according to the SP method using manufacturer instructions. A brownyellow cytoplasm indicated positive staining, and the expression intensity of Fas was inversely determined by the average gray value obtained with the image analysis system; the higher the average gray value, the lower the level of Fas.

\section{Statistical analysis}

Experimental data are reported as means \pm SD. Comparisons between different groups were conducted by the $t$-test using the SPSS version 13.0 software (SPSS, Chicago, IL, USA).

\section{RESULTS}

\section{Changes in survival rates of tumor cells}

The cell growth was inhibited in a dose-dependent manner by MTE, and there were significant differences between different groups $(\mathrm{P}<0.05)$ (Figure 1A). Similarly, the cell growth was suppressed by doxorubicin $(\mathrm{P}<0.05)$ (Figure 1B). More importantly, the combination of $50 \mathrm{mg} / \mathrm{mL}$ MTE and $1 \mu \mathrm{g} / \mathrm{mL}$ doxorubicin showed stronger inhibition than the individual application of MTE or doxorubicin (Figure 1C). Furthermore, the cell growth was inhibited in a time-dependent manner because the survival rate of MG63 cells was the lowest at $72 \mathrm{~h}$ and the highest at $24 \mathrm{~h}$ (Figure 1A-C).

\section{Morphological changes of apoptosis of MG63 cells}

Under inverted phase contrast microscopy, MG63 cells appeared attached to the dish and angular (Figure 2A). With individual application of MTE $(50 \mathrm{mg} / \mathrm{mL})$ or doxorubicin (1 
$\mu \mathrm{g} / \mathrm{mL}$ ), part of the cells became small and round (Figure 2B and C), However, with the combined application, many cells became nonadherent and suspended in the culture medium (Figure 2D). Under fluorescence microscopy, osteosarcoma cells appeared lightly stained (Figure $2 \mathrm{E})$. With individual application of MTE $(50 \mathrm{mg} / \mathrm{mL})$ or doxorubicin $(1 \mu \mathrm{g} / \mathrm{mL})$, only a few cells showed flared fluorescence (Figure $2 \mathrm{~F}$ and $\mathrm{G}$ ). With the combination of MTE (50 mg/ $\mathrm{mL})$ and doxorubicin $(1 \mu \mathrm{g} / \mathrm{mL})$, obvious condensed and flared fluorescence was observed, suggesting the presence of many apoptotic cells (Figure $2 \mathrm{H}$ ).

A

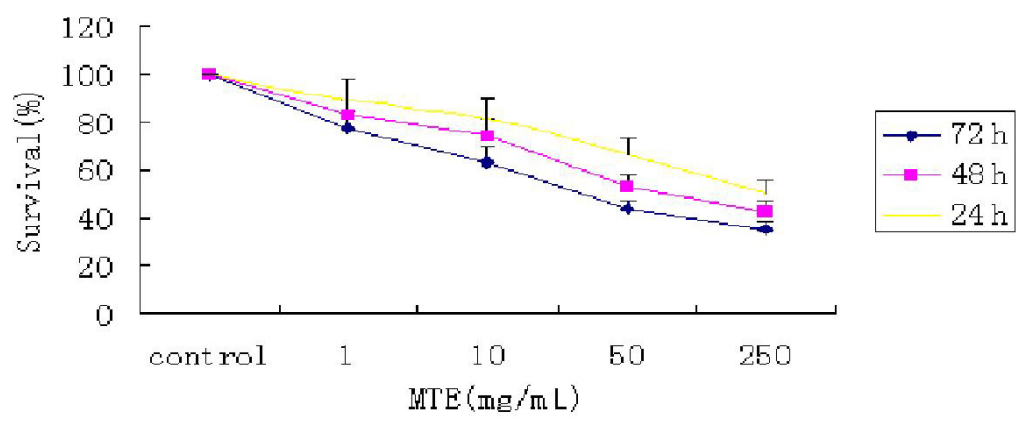

B

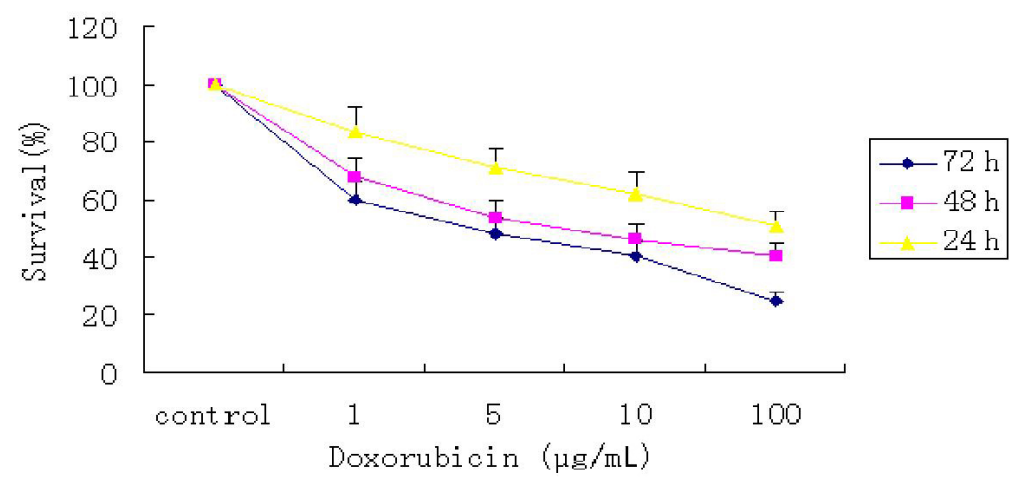

C

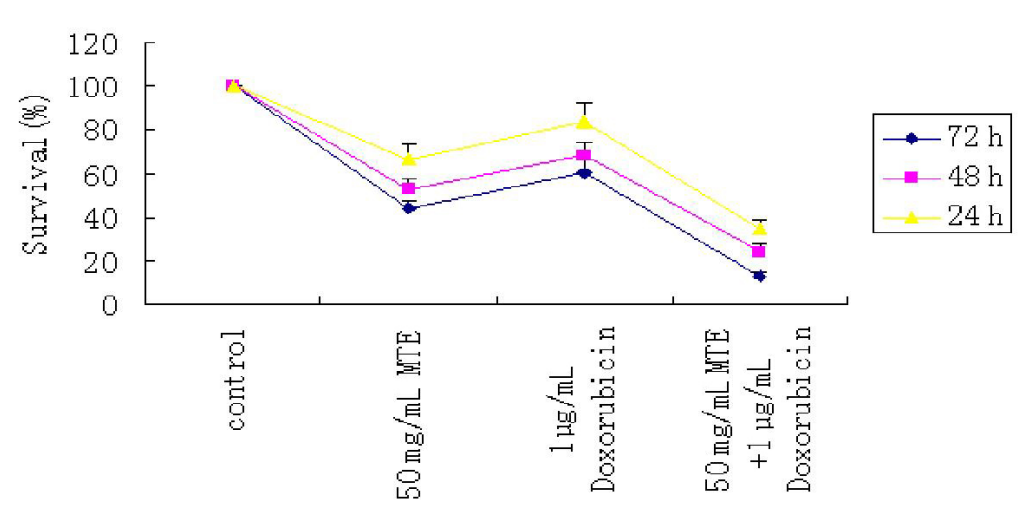

Figure 1. Inhibition effect on MG63 cells after 24, 48, and 72 h, measured by MTT. A. Survival rate of MG63 cells with different concentrations of MTE. B. Survival rate of MG63 cells with different concentration of doxorubicin. C. Survival rate of MG63 cells with combination of $50 \mathrm{mg} / \mathrm{mL}$ MTE and $1 \mu \mathrm{g} / \mathrm{mL}$ doxorubicin. 
A

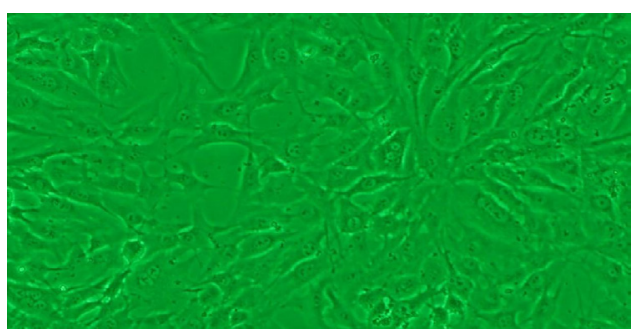

\section{C}

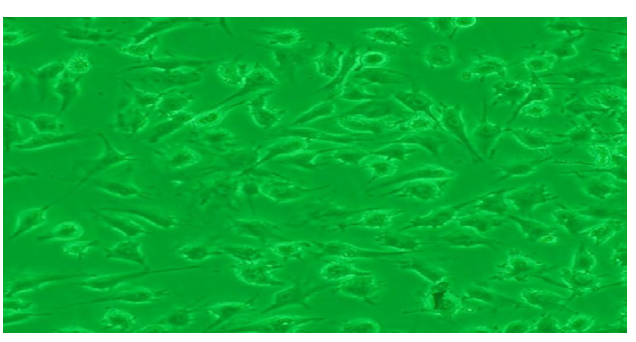

E

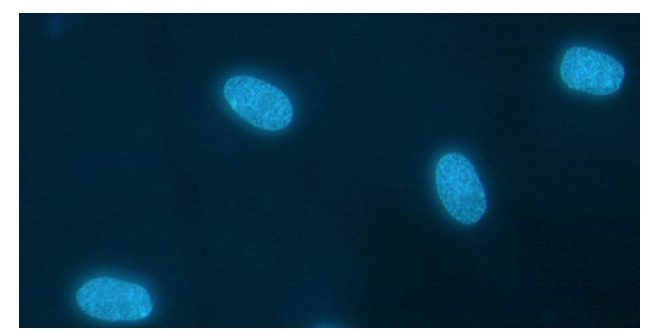

G

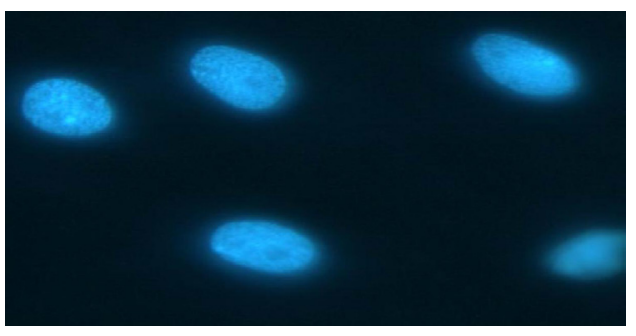

B

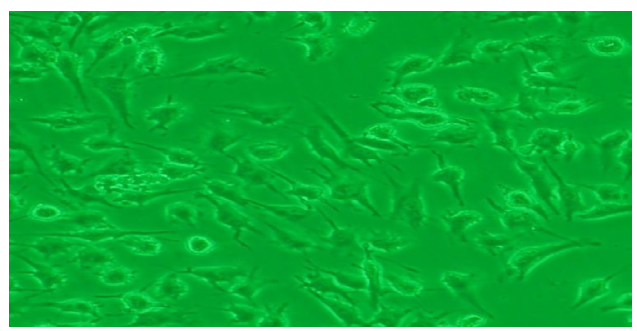

D

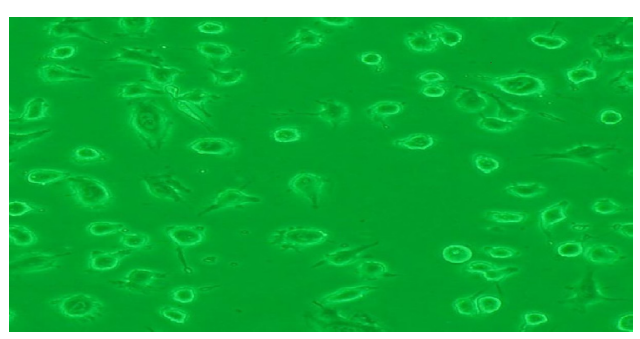

F

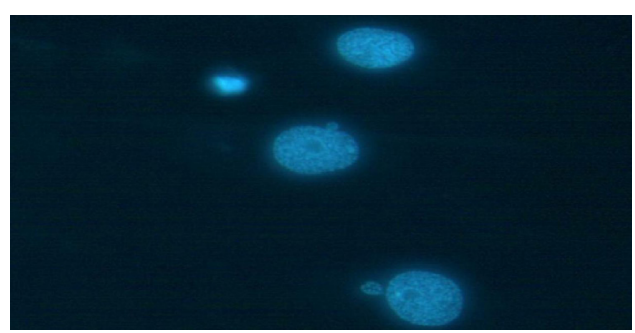

H

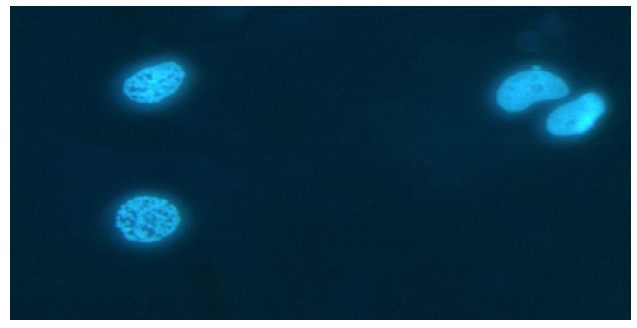

Figure 2. Morphological changes and fluorescent staining of MG63 cells after $72 \mathrm{~h}$ of treatment with different drugs and concentrations. A. Morphological appearance of MG63 cells under the inverted phase contrast microscope at 400X magnification. B. Morphological changes of MG63 cells treated with $50 \mathrm{mg} / \mathrm{mL} \mathrm{MTE}$ under the inverted phase contrast microscope at 400X magnification. C. Morphological changes of MG63 cells treated with $1 \mu \mathrm{g} / \mathrm{mL}$ doxorubicin under the inverted phase contrast microscope at 400X magnification. D. Morphological changes of MG63 cells treated with a combination of $50 \mathrm{mg} / \mathrm{mL}$ MTE and $1 \mu \mathrm{g} / \mathrm{mL}$ doxorubicin under the inverted phase contrast microscope at 400X magnification. E. Fluorescent staining of MG63 cells under the fluorescence microscope at 400X magnification. F. Fluorescent staining of MG63 cells treated with $50 \mathrm{mg} / \mathrm{mL}$ MTE under the fluorescence microscope at 400X magnification. G. Fluorescent staining of MG63 cells treated with $1 \mu \mathrm{g} / \mathrm{mL}$ doxorubicin under the fluorescence microscope at 400X magnification. H. Fluorescent staining of MG63 cells treated with $50 \mathrm{mg} / \mathrm{mL}$ MTE and $1 \mu \mathrm{g} / \mathrm{mL}$ doxorubicin under the fluorescence microscope at $400 \mathrm{X}$ magnification. 


\section{Comparison of apoptotic rates of MG63 cells}

With various concentration of MTE or doxorubicin, the apoptotic rate increased in a dose-dependent manner. There were significant differences between the different groups $(\mathrm{P}<$ $0.05)$ (Figure 3A and B). The apoptotic rate after the combination of MTE $(50 \mathrm{mg} / \mathrm{mL})$ and doxorubicin $(1 \mu \mathrm{g} / \mathrm{mL})$ was significantly higher than after the individual application of MTE $(50 \mathrm{mg} / \mathrm{mL})$ or doxorubicin $(1 \mu \mathrm{g} / \mathrm{mL})(\mathrm{P}<0.01)$ (Figure $3 \mathrm{C})$.

A

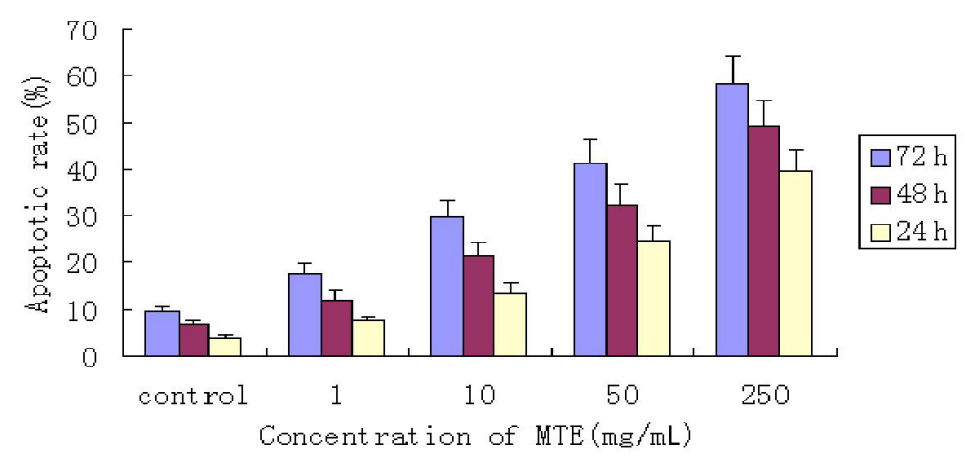

B

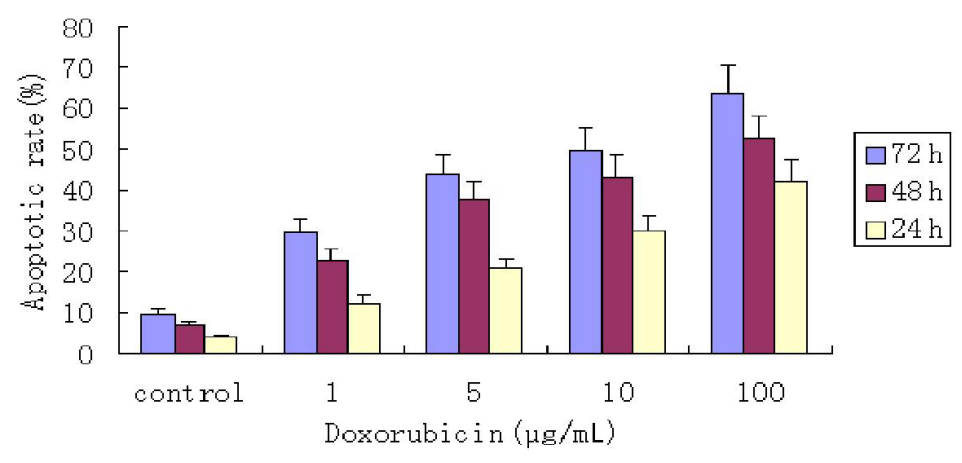

C

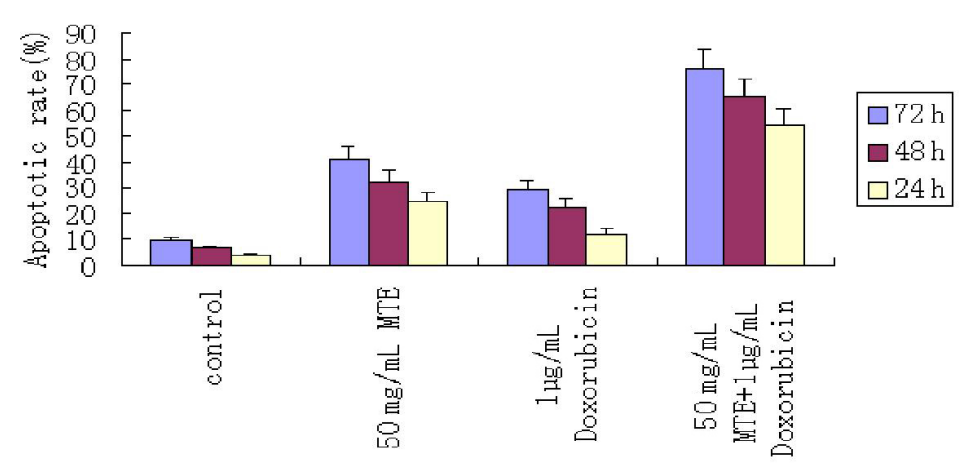

Figure 3. Apoptotic effect observed with MG63 cells after 24, 48, and 72 h treatment with different drugs. A. Apoptotic rate of MG63 cells treated with different concentrations of MTE. B. Apoptotic rate of MG63 cells treated with different concentrations of doxorubicin. C. Apoptotic rate of MG63 cells treated with a combination of $50 \mathrm{mg} /$ $\mathrm{mL}$ MTE and $1 \mu \mathrm{g} / \mathrm{mL}$ doxorubicin. 


\section{Fas expression of MG63 by immunocytochemistry}

We observed only a small amount of brown particles in the cytoplasm of MG63 cells in the control group (Figure 4A). Deeper staining of the cytoplasm of MG63 cells was observed with $50 \mathrm{mg} / \mathrm{mL}$ MTE (Figure 4B) or $1 \mu \mathrm{g} / \mathrm{mL}$ doxorubicin (Figure 4C). With the combination of $50 \mathrm{mg} / \mathrm{mL}$ MTE and $1 \mu \mathrm{g} / \mathrm{mL}$ doxorubicin, the deepest staining was observed (Figure 4D). All of the above results revealed that Fas expression was up-regulated by the combination therapy, which was further verified by comparing the average gray values using the Meta Morph image analyzer (Figure 4E).
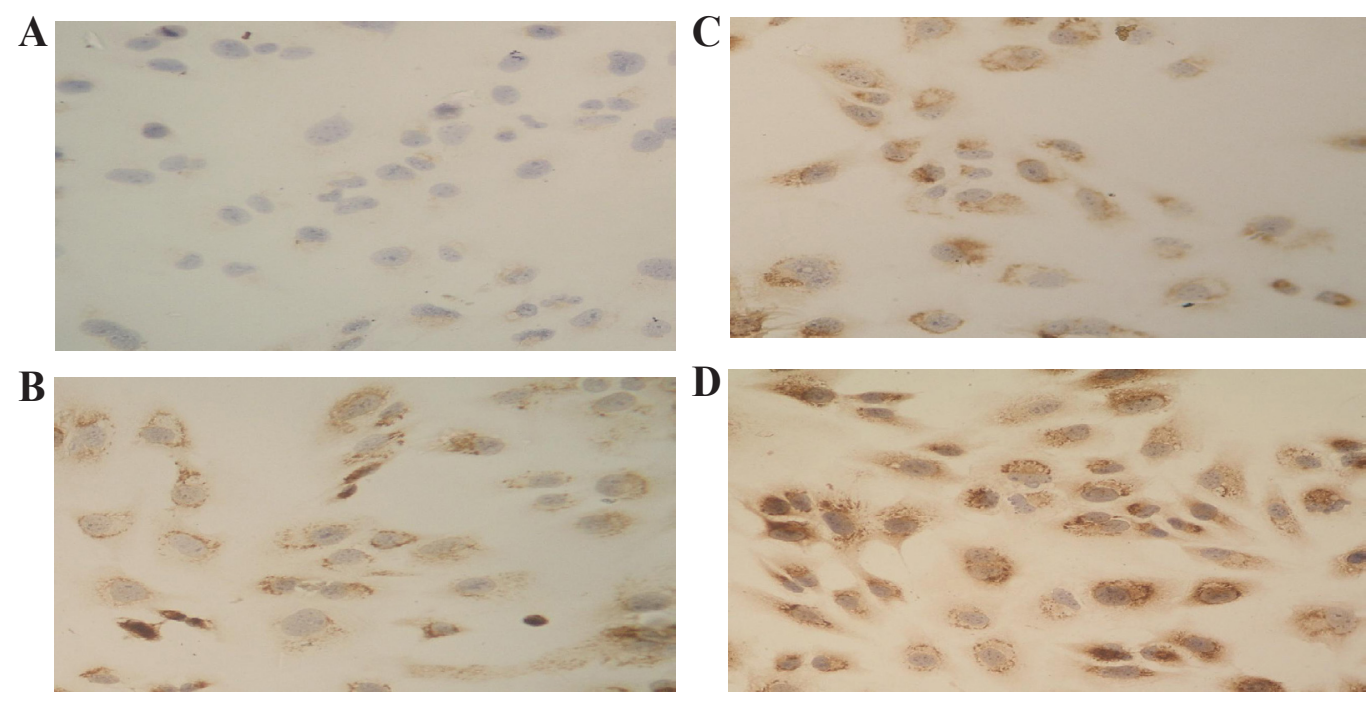

$\mathbf{E}$

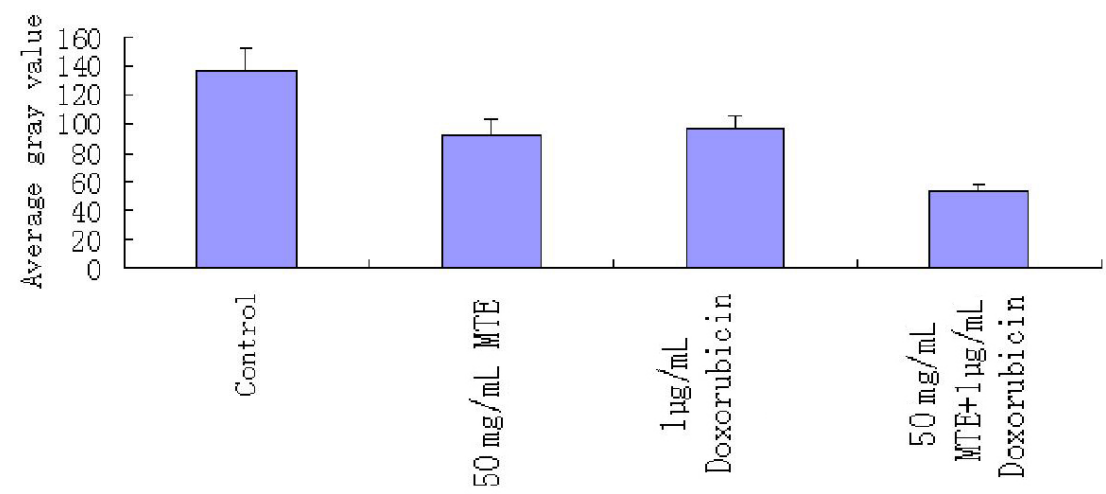

Figure 4. Fas expression in MG63 cells after $72 \mathrm{~h}$ of treatment with different drugs. A. Fas expression in MG63 cells by immunocytochemistry at $400 \mathrm{X}$ magnification. B. Fas expression in MG63 cells treated with $50 \mathrm{mg} / \mathrm{mL}$ MTE by immunocytochemistry at 400X magnification. C. Fas expression in MG63 cells treated with $1 \mu \mathrm{g} / \mathrm{mL}$ doxorubicin by immunocytochemistry at 400X magnification. D. Fas expression in MG63 cells treated with a combination of $50 \mathrm{mg} / \mathrm{mL}$ MTE and $1 \mu \mathrm{g} / \mathrm{mL}$ doxorubicin by immunocytochemistry at $400 \mathrm{X}$ magnification. E. Quantitative analysis of the Fas expression level by comparing the average gray value of different groups using the Meta Morph image analyzer software. 


\section{DISCUSSION}

Xiao-Ai-Ping injection is a Chinese medicine prepared from MTE that has been extensively used in the clinic to treat a number of cancers (Koumtebaye et al., 2012; Han et al., 2012; Xue et al., 2012). However, little is known about the killing effect of MTE on osteosarcoma. Experimental pharmacodynamics and clinical studies both indicate that MTE has a clear killing effect on many kinds of tumor cells, and the mechanism may be related to an apoptosis-inducing effect on tumor cells (Li et al., 2008; Chen et al., 2009; Xue et al., 2012).

Our research indicated that MTE inhibited the proliferation of MG63 cells in a dosedependent manner, consistent with the above described research results. According to our observations, after $72 \mathrm{~h}$ of treatment, when the concentration of MTE increased from 1 to 250 $\mathrm{mg} / \mathrm{mL}$, the survival rate was reduced only from 77.53 to $35.16 \%$, which revealed that MG63 cells were not very sensitive to MTE (Figure 1A). When the concentration of doxorubicin increased from 1 to $100 \mu \mathrm{g} / \mathrm{mL}$, the survival rate was reduced from 60.25 to $24.85 \%$, which indicated that osteosarcoma cells were more sensitive to doxorubicin, and the antitumor effect of doxorubicin was stronger than MTE (Figure 1B). All of these results were consistent with the main view in the clinical treatment that doxorubicin is the first-line anticancer drug for chemotherapy and that MTE is an adjuvant that may improve the immunity function to prevent the recurrence of the tumor after the regular chemotherapy is completed. According to our results, MTE is suitable for the treatment of osteosarcoma. To our surprise, after $72 \mathrm{~h}$ of combination treatment with $50 \mathrm{mg} / \mathrm{mL}$ MTE and $1 \mu \mathrm{g} / \mathrm{mL}$ doxorubicin, using the MG63 cell line, the survival rate decreased sharply to $12.73 \%$. The synergistic killing effect was clearly much stronger than when using MTE or doxorubicin individually (Figure 1C). This suggested that a greater antitumor effect is triggered if MTE is used together with doxorubicin during chemotherapy. In addition, our research showed that the killing effect of MTE and doxorubicin was achieved by inducing apoptosis of osteosarcoma cells, based on the cell morphology (Figure 2A-D), cell apoptosis detection (Figure 2E-H), and FCM analysis (Figure 3A and B).

Fas is a trans-membrane protein of tumor necrosis factor receptor superfamily (Inoue et al., 2009; Matsuda et al., 2009; Akimzhanov et al., 2010; Liedtke and Trautwein, 2012) and is expressed extensively on the cytoplasmic membrane. When Fas is bound to its ligand, the apoptotic signal may be transferred to the cells. Many antitumor agents induce apoptosis of tumor cells by up-regulating the expression of Fas (Okamoto et al., 2006; Kim et al., 2007; Dai et al., 2009). However, little is known about the regulation of the Fas level triggered by MTE. Our research indicated that $72 \mathrm{~h}$ after the combination treatment of $50 \mathrm{mg} / \mathrm{mL}$ MTE and $1 \mu \mathrm{g} / \mathrm{mL}$ doxorubicin, the apoptosis rate was $76.03 \%$, far greater than individual application of $50 \mathrm{mg} / \mathrm{mL}$ MTE or $1 \mu \mathrm{g} / \mathrm{mL}$ doxorubicin (Figure 3C). Furthermore, Fas expression in MG63 cells improved significantly in the combination group compared with individual administration of MTE or doxorubicin (Figure 4A-E). Therefore, we conclude that the Fas pathway plays a critical role in achieving this synergistic effect.

In conclusion, we determined the potential effects of MTE on osteosarcoma cells using analytical methods. Our research indicates that MTE can be used to increase the antitumor effect of doxorubicin while suppressing the side-effects of chemotherapy by allowing the use of a decreased dose of doxorubicin. As a plate-based biotechnology product, MTE is much safer than common chemical drugs such as doxorubicin. Therefore, we believe that MTE supplementation is a useful antitumor method for the clinical treatment of osteosarcoma. 


\title{
ACKNOWLEDGMENTS
}

\author{
Research supported by the Science and Technology Department of Liaoning Province \\ (Project \#2013225021).
}

\section{REFERENCES}

Akimzhanov AM, Wang X, Sun J and Boehning D (2010). T-cell receptor complex is essential for Fas signal transduction. Proc. Natl. Acad. Sci. U. S. A. 107: 15105-15110.

Broadhead ML, Dass CR and Choong PF (2011). Systemically administered PEDF against primary and secondary tumours in a clinically relevant osteosarcoma model. Br. J. Canc. 105: 1503-1511.

Chen B, Li CP and Chen JH (2009). Inhibiting effect and apoptosis-inducing effect of extract of Marsdenia tenacissima on leukemia cells. J. Nanjing Univ. Tradit. Chin. Med. 25: 233-234.

Dai ZJ, Gao J, Ji ZZ, Wang XJ, et al. (2009). Matrine induces apoptosis in gastric carcinoma cells via alteration of Fas/ FasL and activation of caspase-3. J. Ethnopharmacol. 123: 91-96.

Dotan A, Dadia S, Bickels J, Nirkin A, et al. (2010). Expandable endoprosthesis for limb-sparing surgery in children: long-term results. J. Child. Orthop. 4: 391-400.

Fang YQ and Sun XM (2011). Review on Marsdenia tenacissima's chemical components and their antitumor mechanism. Chin. J. Biochem. Pharm. 32: 165-167.

Han SY, Zhao MB, Zhuang GB and Li PP (2012). Marsdenia tenacissima extract restored gefitinib sensitivity in resistant non-small cell lung cancer cells. Lung Canc. 75: 30-37.

Inoue S, Harper N, Walewska R, Dyer MJ, et al. (2009). Enhanced Fas-associated death domain recruitment by histone deacetylase inhibitors is critical for the sensitization of chronic lymphocytic leukemia cells to TRAIL-induced apoptosis. Mol. Canc. Ther. 8: 3088-3097.

Kim JS, Lee YC, Nam HT, Li G, et al. (2007). Apicularen A induces cell death through Fas ligand up-regulation and microtubule disruption by tubulin down-regulation in HM7 human colon cancer cells. Clin. Canc. Res. 13: 6509-6517.

Koumtebaye E, Su N and Hu WF (2012). Antitumor activity of Xiaoaiping injection on human gastric cancer SGC-7901 cells. Chin. J. Nat. Med. 10: 339-346.

Lei YS, Li ZL, Yang SS, Liu ZL, et al. (2008). C21 steroids from the stems of Marsdenia tenacissima. Yao Xue Xue Bao 43: 509-512.

Li D, Yang J and Li C (2008). Effect of Marsdenia tenacissima on the poptosis-associated gene expression profile of U937 cells. Chin. J. Biochem. Pharm. 29: 240-243.

Liedtke C and Trautwein C (2012). The role of TNF and Fas dependent signaling in animal models of inflammatory liver injury and liver cancer. Eur. J. Cell Biol. 91: 582-589.

Matsuda N, Yamamoto S, Takano K, Kageyama S, et al. (2009). Silencing of fas-associated death domain protects mice from septic lung inflammation and apoptosis. Am. J. Respir. Crit. Care Med. 179: 806-815.

Okamoto K, Fujisawa J, Reth M and Yonehara S (2006). Human T-cell leukemia virus type-I oncoprotein Tax inhibits Fas-mediated apoptosis by inducing cellular FLIP through activation of NF-kappaB. Genes Cells 11: 177-191.

Qian J, Hua H and Qin S (2009). Progress on antitumor effects of Marsdenia tenacissima. Zhongguo Zhong. Yao Za Zhi. 34: 11-13.

Xue HL, Huang XD, He D, Lin SJ, et al. (2012). Effects of Marsdenia tenacissima extract on proliferation and apoptosis of hematologic neoplasm cell line cells. Sichuan. Da Xuе Xue Bao Yi. Xue Ban. 43: 174-179.

Zhang F, Chen A, Chen J, Yu T, et al. (2011). SiRNA-mediated silencing of beta-catenin suppresses invasion and chemosensitivity to doxorubicin in MG-63 osteosarcoma cells. Asian Pac. J. Canc. Prev. 12: 239-245.

Zhang H, Tan AM, Zhang AY, Chen R, et al. (2010). Five new C21 steroidal glycosides from the stems of Marsdenia tenacissima. Steroids 75: 176-183. 